\title{
Konkrete udspil for ukonkrete udslip: politisk kommunikation om klima i 2009 og 2019
}

Pernille Almlund, lektor, Institut for Kommunikation og Humanistisk Videnskab, Roskilde Universitet

Artiklen er en sammenligning af politisk kommunikation om klima, som den var blandt politikerne på Christiansborg i 2009/10 med, hvordan den tager sig ud her i 2019. Sammenligningen baserer sig på interview med politikere i 2009/10 og partiernes klimaudspil fra 2018/19. Artiklen argumenterer for, at der er tale om at sammenligne den mest fyldestgørende information om partiernes klimapolitik $i$ de to perioder. Analysen med en systemteoretisk indfaldsvinkel viser, at politikernes kommunikation om klima er gået fra i 2009 at vore ret abstrakt til i 2019 at vore ret konkret. Herudover viser analysen, at den nuvarende mere konkrete kommunikation om klima baserer sig på tal og beregninger, som er blevet den dominerende kommunikationsform blandt politikerne, når de taler om klima.

Årene 2009 og 2019 er begge år med særlig stor betydning for debatten om klimaforandringer i dansk politik. I 2009 skulle COP15 afholdes i København, og de fleste politiske partier fik derfor en grønnere profil end tidligere. I 2019 er de danske vælgere optaget af klima og udpeger det til at være et af de vigtigste temaer for årets valgkamp, hvilket har været svært for politikerne helt at sidde overhørig.

I 2009 betød det, at klimadagsordenen fyldte på Christiansborg, men fordi der var indgået borgfred mellem partierne for at sikre den gode og stringente gennemførelse af COP15, blev diskussionerne først politisk betændte efter COP mødets afslutning. Det betød også, at klima var på borgernes dagsorden, og det betød, at der blev skrevet og fortalt meget om klimadagsordenen i de danske medier (Danielsen 2015; Eskjær 2014). Her i 2019, og ligeså i 2018, fylder det igen i både den politiske debat og i medier, og denne gang er der ingen borgfred, der tager brodden ud af de skarpe politiske beskyldninger, der således huserer i både medier og på borgen. Fælles for de to år er imidlertid, at alle partier har fokus på klimaforandringer og diskussioner om politisk handling, dog med forskellig intensitet og mål.

Når de her to årstal kommer til at stå frem (2009/10 og 2018/19), så er det fordi, tiden imellem de år har været præget af stilstand eller normalisering af klimadebatten. 
Stilstand, fordi andre politiske debatter har fyldt langt mere, og kun enkelte oppositionspartier har forsøgt at råbe de respektive regeringer op. Normalisering, fordi vi har kunnet se klimadagsordenen i medierne, blot ikke i samme omfang som i 2009 (Danielsen 2015; Eskjær 2014; 2016), og som oftest ikke som selvstændigt omdrejningspunkt for mediedækningen. Det har typisk været som del af den politiske og økonomiske journalistik eller som en del af forbruger-journalistikken (Almlund og Danielsen 2016).

Med globale problemer som klimaforandringerne er det derfor væsentligt at vende blikket mod vores politikere og deres politiske arbejde. Den måde politikerne kommunikerer om klima, hvordan de forstår klima og lægger op til at håndtere klimaforandringer er af stor betydning for, hvad der bliver gjort. Det gælder i Danmark, der er omdrejningspunktet for denne artikel, som det gælder i alle andre lande på kloden.

Artiklen falder i fem dele. Første afsnit præsenterer de data, analyserne af henholdsvis 2009 og 2019 baserer sig på. Næste afsnit præsenterer artiklens teoretiske tilgang og de specifikke analytiske greb, der er gjort brug af. Begreber og inspiration er her hentet fra Niklas Luhmanns systemteori. Dernæst kommer første del af analysen, der viser, hvordan de forskellige partier tildeler mening til klima, og herefter følger anden del af analysen, der viser, hvilken kommunikationsform der sætter rammen om politikeres kommunikation om klima. Slutteligt er der et konkluderende afsnit.

\section{Politisk kommunikation via interview og klimaudspil}

I tiden efter COP 15 interviewede jeg alle klima- og/eller miljøordførere for partierne, der sad i Folketinget på det tidspunkt. Det gjorde jeg for at få indtryk af, hvordan politikere og partier kommunikerede om og forstod klima i deres politiske virke (Almlund 2012). Jeg ville gerne vide, om der på trods af politiske forskelle kunne spores ligheder, men naturligvis også identificere forskellene. Jeg fandt begge dele.

Interviewene fokuserede på det enkelte partis holdning til klima og var ikke tænkt som den individuelle interviewedes holdning til samme. Selvom ikke alle partier på det tidspunkt havde en eksplicit klimapolitik, var klima et diskuteret emne blandt politikerne i 2009. Det var f.eks. tydeligt ved, at Dansk Folkeparti, der ikke blev identificeret som et specielt klimainteresseret parti, i efteråret 2009 havde arrangeret et symposium om netop klima på Christiansborg. Klima blev diskuteret i alle partier og var noget, de forholdt sig til op til COP 15 - andet havde også været mærkeligt, når nu COP-mødet skulle afholdes i København.

Klima var også stærkt omtalt i medierne i 2009 - faktisk til et niveau, hvor medierne begyndte at omtale borgernes klimakvalme (Nielsen 2009; Klingenberg 2009). Relativt hurtigt efter COP 15, da kritikken havde lagt sig, fyldte det hverken meget i medierne eller på Christiansborg. En af de interviewede ordførere tilkendegav ca. et halvt år efter COP-mødet, at der nu kun blev talt om klima i økonomiske termer i Folketingssalen, hvilket var en markant forskel til 2009-diskussionen om klima og partiernes borgfred op til COP15 (Almlund 2012). 
I løbet af 2018 og 2019 er der lanceret klimaudspil eller -planer fra den borgerlige VKL-regering (Venstre, Det Konservative Folkeparti og Liberal Alliances) og alle øvrige partier i Folketinget ${ }^{1}$. Dansk Folkepartis udspil skiller sig dog ud ved først at være bragt i september og dermed efter Folketingsvalget og har i forlængelse af det også en anden karakter end de øvrige udspil. Liberal Alliance har udover at være del af VKL-regeringens klimaudspil lanceret en egen 2030 plan med 5 klimapolitiske mål og en række statements $^{2}$. Det har ingen af de øvrige regeringspartier gjort, hvorfor partierne i VKL-regeringen ses som samlet i analysen. Herudover er der udspil og planer fra Enhedslisten, Socialistisk Folkeparti, Alternativet, Socialdemokratiet og Radikale. Det er den række af udspil og planer, der indgår i analysen af partiernes kommunikation om og forståelse af klima for 2019 og det er dem, der vil blive sammenlignet med analysen af interview med klima- og miljøordførerne fra Enhedslisten, Socialistisk Folkeparti, Socialdemokratiet, Radikale, Det Konservative Folkeparti, Venstre, Dansk Folkeparti og Liberal Alliance fra 2009/10.

Artiklen her er primært koncentreret om analysen af udspillene, da denne ikke er foretaget tidligere, mens analysen fra 2009/10 er tilstede som sammenligningsgrundlag for netop at have mulighed for at se på udviklingen af den politiske kommunikation om klima. Analysen fra 2009/10 og hele indfaldsvinklen til analysen er grundigt beskrevet i en tidligere artikel (Almlund 2012).

Der er på den måde tale om en analyse af kvalitative semistrukturerede interview (Denzin \& Lincoln 2003; Kvale \& Brinkmann 2015; la Cour et al. 2005) med klima- og miljøordførere i sammenligning med en kvalitativ analyse af nedskrevne politiske klimaudspil. For de to specifikke år er det måden at opnå den mest fyldestgørende information om partiernes kommunikation af klimapolitik. I 2009/10 måtte det være via interview, da partierne endnu ikke var stærkt eksplicitte på skrift om deres klimapolitik, og her i 2018/19 er det netop via partiernes fyldestgørende udspil og planer, at vi får mest information om deres klimapolitik. På den måde er analysen en sammenligning af den mest eksplicitte partipolitiske kommunikation om klima. Med teoretisk inspiration fra Niklas Luhmann giver det hertil mening, da det hele er at betragte som klima-kommunikation og skal analyseres som sådan. Den analytiske indfaldsvinkel og fremgangsmåde har på den måde været den samme i begge analyser.

Teori

Luhmanns systemteori er genstand for en kort præsentation i dette afsnit. Luhmanns teori er omfattende og abstrakt men analytisk potent. Det sidste er årsagen til, at den er i brug her. Det er kun dele af teorien, der bliver præsenteret her for at vise relevansen af det blik, når det er politisk kommunikation om klima, der er omdrejningspunktet.

\footnotetext{
${ }^{1}$ Som Folketinget var sammensat fra 2015 til juni 2019.

${ }^{2}$ Jeg har udeladt Liberal Alliances eget udspil fra analysen, da det er særdeles kortfattet og ikke tilføjer noget til analysen.
} 
Luhmann tager sit udgangspunkt i, at samfundet består af funktionelle systemer, hvor han blandt andre systemer definerer det politiske system, det videnskabelige system, det økonomiske system, mediesystemer og flere til (Luhmann 2002; 2000; 1990). Der er tale om sociale systemer til forskel fra f.eks. psykiske systemer og biologiske systemer (Luhmann 2000).

Alle systemer er ifølge Luhmann 'autopoietiske', hvilket vil sige selvrefererende og selvproducerende (Luhmann 2000). Ethvert system har derved sin egen logik og binære kode, som f.eks. det politiske system, hvis binære kode er magt/opposition (Luhmann 1990). Systemerne er på den måde lukkede for hinanden og agerer efter egne logikker. Dog kan systemerne lade sig irritere og forstyrre af omverdenen og dermed af andre systemer - de er så at sige autopoietisk lukkede, men kognitivt åbne (Luhmann 1992).

Alle sociale systemer består af kommunikation og ikke af individers handlinger, men der skal personer til at gennemføre kommunikation. Hermed fjerner Luhmann fokus fra individer og deres motiver for handling og koncentrerer sig om den kommunikative interaktion, fordi det er kommunikation og interaktion, der udvikler og konstituerer samfundet og dets systemer. Derfor er det kommunikationen, vi skal iagttage for at forstå, hvad der foregår i samfundet og de sociale systemer.

Kommunikation skal med Luhmann forstås som en enhed af tre selektioner, nemlig selektionen af en information, selektionen af en måde at formidle denne på og selektionen af forståelse hos den, kommunikationen er rettet mod (Luhmann 2000; Kneer \& Nassehi 1997). Selektionen af forståelse ses i den fortsatte kommunikation, hvor den, der før var modtager af kommunikationen, nu selekterer en information og en måde at formidle denne på. Sådan fortsætter processen i enhver kommunikativ interaktion som f.eks. i helt almindelige samtaler. Der er altså ikke tale om overførsel af informationer i interaktionen men om en fortsat fortolkningsproces.

Iagttagelse er hos Luhmann noget, der sker hele tiden, da det er iagttagelser, vi giver udtryk for, når vi kommunikerer. Samtidig er iagttagelse et analytisk begreb, der kan hjælpe os, når vi skal finde ud af, hvad der kommunikeres frem som det vigtige i de forskellige systemer.

Iagttagelse er ifølge Luhmann defineret som enheden af en skelnen mellem det, der bliver markeret versus det umarkerede. Iagttager man f.eks. en person, kan man markere vedkommende som en kvinde og dermed sætte mand, pige, dame og andet på den umarkerede side af den skelnen. En sådan skelnen er altid til stede i vores iagttagelser, men er ikke altid noget vi er bevidste om. Luhmann definerer både 1. og 2. ordens iagttagelser. 1. ordens iagttagelser er de iagttagelser, hvor vi ikke er bevidste om, at vi foretager en skelnen mellem det markerede og det umarkerede og hvad vi på den måde lader ude af syne på den umarkerede side. 1. ordens iagttagelsen tager, med andre ord, det iagttagede for givet. Heroverfor står 2. ordens iagttagelsen, der er iagttagelse af 1. ordens iagttagelser og af mere analytisk karakter. 2. ordens iagttagelsen er på den måde en iagttagelse af begge sider af skellet $i$ 1. ordens iagttagelser og er analytisk ved netop at kunne pege på, at den selvfølgelige markering i 1. ordens iagttagelsen også kunne have været en 
anden (Luhmann 1995; Kneer og Nassehi 1997). Det er væsentligt, fordi den umarkerede side er med til at vise det markerede, da f.eks. kvinde i forhold til mand er noget andet end kvinde i forhold til pige og igen noget helt andet end kvinde i forhold til dame. Betydningen af det markerede er så at sige holdt på plads af det, der forblev umarkeret, men som det markerede blev skelnet fra.

Hertil kommer, at enhver iagttagelse har en blind plet, og det gælder både 1. og 2. ordens iagttagelser. Igen er forskellen dog, at 1. ordens iagttagelsen ikke er bevidst om den blinde plet, mens 2. ordens iagttagelsen er bevidst om den uden at være i stand til at se egen blinde plet i øjeblikket for iagttagelsen. Det er den i stand til efterfølgende ved en 2. ordens iagttagelse af egen tidligere iagttagelse (Luhmann 1995; Andersen 1999).

Analysen af de politiske udspil og analysen af interviewene fra 2009/10 er 2. ordens iagttagelse af politisk kommunikation om klima og forudsætning for at foretage henholdsvis en semantisk analyse og en formanalyse af materialet.

I den semantiske analyse (Luhmann 2016; Andersen 1999; 2014) leder man efter, hvordan der tildeles mening til det begreb eller tema, man er ved at undersøge, så i dette tilfælde hvordan politikere og politiske partier tildeler mening til klima i deres kommunikation. I den analyse ser man efter, hvad der på den umarkerede side holder betydningen af den markerede side på plads, man forsøger at identificere begrebets modbegreb, da ethvert begreb ifølge Luhmann har et modbegreb, der kommer til udtryk i konteksten (Andersen 1999). Derudover kan man søge efter andre typer af skelnen, hvor vi her vil fokusere på, hvordan begrebet bliver kategoriseret. Det at kategorisere er ligeledes at lade andet forblive på den umarkerede side. Det helt centrale her er, at der i enhver kommunikation og enhver iagttagelse er tale om skelnen, som forklaret ovenfor. Det betyder, at man i sin søgen efter modbegreb og kategorisering leder efter de skel, som begrebet og kategoriseringen kan udtrykkes igennem. Man skal hele tiden have blik for både den markerede og den umarkerede side.

Skellene er selvsagt talrige i kommunikationen, men lægger sig typisk også efter et mønster i den specifikke kontekst og knytter an til det, Luhmann kalder kommunikationsformen (Luhmann 1997; Andersen 1999; 2003). Kommunikationsformen er derved rammen om kommunikationen og er derfor væsentlig at identificere. Det er den, vi forsøger at identificere med formanalysen. Kommunikationsformen er ikke umiddelbart synlig, men er den blinde plet, det fundament som kommunikationen står på. Hermed forsøger vi at finde frem til den blinde plet - den kommunikationsform der binder de mange forskellige iagttagelser og tildelinger af mening om klima sammen. Vi leder så at sige efter enheden af forskellene. På den måde hænger den semantiske analyse sammen med formanalysen.

I den søgen efter enheden af forskellene mellem de mange iagttagelser, som politikerne gør om klima, leder vi altså efter lige præcis den kommunikationsform, der har betydning for den generelle kommunikation om klima blandt politikere. Vi leder ligeså efter, hvilken forskel kommunikationsformen udtrykker sig igennem, og som gælder for alle de skel, vi iagttager i kommunikationen. 
Kommunikationsformen er grundlæggende paradoksal og adskiller, hvad der ikke naturligt kan adskilles. På den måde er relationen mellem forskellens markerede side og umarkerede side en umulighedsrelation, og formanalysen vil sige at specificere kommunikationsformens umulighedsbetingelser, som kommunikationen er tvunget til at skabe muligheder ud af. Det, vi leder efter med formanalysen, er det, som er selvfølgeliggjort, og som driver kommunikationen dynamisk frem, men som samtidig er en umulighedsrelation (Almlund 2007; Almlund 2019; Andersen 1999).

Med den Luhmanske ammunition begiver vi os nu ind i analysen og leder efter, hvordan partier og politikere kommunikerer om klima med fokus på både de forskellige tildelinger af mening, der kan være partierne imellem og de ligheder, der kan være, når man er del af det politiske system og skal diskutere temaet med hinanden.

\section{Partiernes forståelser af klima}

I analysen af, hvordan klima- og miljøordførerne tildelte mening til klima i 2009/10, var der en række ligheder partierne imellem, hvor flere af partierne talte om aspekter som teknologi, videnskab, bistandshjælp til 3. verdens lande, massemedier, organisationer, energi, sikkerhedspolitik m.v. i relation til klima (Almlund 2012). Mange af de aspekter ser vi stadig omtalt i de politiske klimaudspil her fra 2018/19, men med de mange flere ord, der nu bliver brugt til at beskrive de respektive politikker, er der også fulgt en anden grad af præcisering med. Hvor nogle i 2009/10 nævnte, at bistandshjælpen til 3. verdens lande skulle forbedres, så er der i dag præcise tal på, hvordan og hvor meget den støtte skal omfatte. Hvor de i 2009/10 talte om vigtigheden af videnskab på et mere overordnet niveau, trækker de her i 2018/19 i langt højere grad på videnskabelige resultater og beregninger. Nogle aspekter er dermed stadig del af politikernes kommunikation om klima her i 2019. Andre er forsvundet, og nye aspekter er kommet til, f.eks. opdelingen mellem den kvotebelagte sektor og den ikke-kvotebelagte sektor. Politikernes kommunikation om klima er blevet langt mere konkret. Det gælder for alle partier undtagen for DF.

Der er også i dag overlap i de forskellige partiers klimaudspil, men ligesom i 2009/10 med forskellig vægt på de forskellige aspekter. Den stærkere konkretisering betyder imidlertid, at de aspekter, der træder tydeligst frem, har en anden karakter. F.eks. er omtale af den kvotebelagte sektor, den ikke kvotebelagte sektor, herunder især landbrug og transport samt tempoet for reduktionsmålene nogle af de aspekter, der tydeligst viser forskellen mellem partiernes klimaudspil. Hertil kommer omtalen af økonomi og finansiering og beregninger af, hvor meget CO2-udslip, vi sparer med de forskellige tiltag. Sådan tegnede billedet sig ikke tilbage i 2009.

I den semantiske analyse er jeg som nævnt på udkig efter modbegrebet til klima og kategoriseringen af klima i politikernes kommunikation om klima i udspillene. Belært af analysen i 2009/10 så udgør hvert partis politiske program om klimaet det respektive partis kategorisering af klima, for der er ikke tale om et enkelt element eller aspekt, der tegner et partis samlede klimapolitik. Derimod er der tale om, at hver af partierne har en 
for dem sammenhængende forståelse af klimaet, der lægger sig op ad partiets ideologi. Det betyder samtidig, at hvert partis sammenhængende forståelse er den, de iagttager som den markerede side, mens de øvrige partiers sammenhængende forståelser er på den umarkerede side og udgør modbegrebet til hver deres forståelse af klima.

Næsten alle partiers udspil er ganske omfattende og kan ikke præsenteres detaljeret inden for rammen af denne artikel. Derfor vælger jeg her at fokusere på de aspekter, der mest tydeligt differentierer udspillene fra hinanden. Det gælder nemlig, at der er relativt stor enighed om, at der skal mere vedvarende energi og mindre fossil energi, selvom der naturligvis også er forskelle her, hvor forskellene afspejler sig i tempo og virkemidler, frem for som tidligere, hvor uenigheden gik på de større linjer om, hvorvidt vedvarende energi skulle prioriteres op eller ej. Herudover er der her i 2019 stor enighed blandt de politiske partier om at foretage konkrete tiltag inden for transportområdet, hvor der bliver peget på elektrificering af bilparken og tiltag, der skal understøtte det, CO2-afgifter på fly og udvikling af grønnere fly og en hel masse mere. Ikke fordi partierne her er fuldstændig enige, hvor især DF skiller sig ud, men der er mange overlap.

For at se på, hvor partierne i særlig grad adskiller sig fra hinanden, er der i præsentationen af partiernes udspil og deres sammenhængende forståelser af klima lagt vægt på de aspekter, hvor partierne tydeligst adskiller sig fra hinanden. Det gælder tiltag på landbrugsområdet, tempoet for reduktionsmålene, økonomiske aspekter, finansiering og på den baggrund, i hvilken grad forslagene er konkretiseret.

\section{Enhedslisten}

Landbrug:

Partiet har mål for, hvor mange hektar af de kvælstofholdige jorde, der skal tages ud af drift, omlægning af landbrugsarealer og en CO2-afgift for udledningen i landmændenes produktion $\mathrm{mm}$.

\section{Tempo for reduktionsmål:}

Partiet stiller forslag om en bindende klimalov, der skal have bindende målsætninger om at gøre Danmark til et nulemissionssamfund senest i 2040, men også, at der skal gøres status over reduktionerne hvert andet år, hvor ideen er, at loven skal forpligte den siddende regering på nye tiltag, hvis ikke reduktionerne er på rette vej.

Partiet lægger også i eget forslag op til, hvor vigtigt det er med løbende status og peger på en overopfyldelse af de fastsatte reduktionsmål for 2050.

\section{$\varnothing$ konomi og finansiering:}

De præsenterer et fuldt finansieret forslag og lægger vægt på, at det er tilfældet: "Du sidder med en samlet og fuldt finansieret klimaplan, der anviser vejen til at reducere Danmarks CO2-udledning med 70 pct. i 2030." (Enhedslisten 2019, 3). Herudover tænker de klima og ulighed sammen således, at afgifter hverken skal ligge de ressourcesvage borgere eller landmændene til last, men skal tilbage til borgerne via en 
udvidet grøn check og til landmanden afhængig af den enkelte bedrifts nedgang i udledning af $\mathrm{CO} 2$.

Der er herudover fokus på, at bistanden til klimatilpasning til de fattigste lande skal hæves til 5 milliarder kr. om året. Herudover skal Danmark gå foran som et godt eksempel og partiet vil gøre op med ideen om grøn vækst.

Forslaget er generelt konkret og med beregnede talværdier, både hvad angår finansieringen, og hvad angår reduktioner af CO2-udslip

\section{Socialistisk Folkeparti}

Landbrug:

Partiet stiller en lang række konkrete forslag til omstilling, såsom forslag til håndtering af gylle, dieselafgift på landbrugsmaskiner, ændrede dyrkningsmetoder, mindre madspild og udtagning af kvælstofholdige jorde. Landbrugsstøtten skal på sigt afskaffes og i første omgang omlægges til at være grøn. Der er derudover et ønske om at finde et alternativ til soja-produkter, hvor en udfasning skal føre til at kompensere de lande, sojaen importeres fra for at beskytte regnskoven. Hertil kommer forskning i miljø- og klimavenligt landbrug.

\section{Tempo for reduktionsmål:}

Partiet peger i deres første forslag på, at de reelt lever op til EU's målsætninger om reduktion af CO2-udslip og sammenstiller med regeringens udspil ved at skrive: "Metoden (regeringens; red.) kan formentlig bruges til at opfylde EU-forpligtelser, men der er ikke tale om en klimaindsats. SF har en række konkrete forslag, der sikrer forbedringer på disse punkter, og som derfor er udtryk for en reel klimaindsats". (Socialistisk Folkeparti 2019a, 4). Den 25. maj, 2019 lancerede SF imidlertid en klimaplan, der har som mål at opnå en CO2-reduktion på 70 \% i 2030 sammenlignet med basisåret 1990 (Socialistisk Folkeparti 2019b). Med det udspil melder SF altså også ind med en ambition om at overopfylde i forhold til EU's målsætning.

\section{$\varnothing$ konomi og finansiering:}

Herudover påpeger de, at regeringens forslag til annullering af 8 mio. CO2-kvoter vil koste 120 mio. kr./år i 10 år. De penge bruger SF i stedet til at indgå i finansieringen af deres forslag. SF's forslag er fuldt finansieret.

Også her nævnes den grønne check i forbindelse med indførelse af klimaafgift på fødevarer, så fordelingsvirkningen ikke bliver skæv. 
Forslagene er generelt konkrete og med beregnede talværdier, både hvad angår finansiering, og hvad angår reduktioner af $\mathrm{CO} 2$-udslip.

\section{Socialdemokratiet}

Landbrug:

Partiets forslag er ikke så konkrete på det område, da det handler om at nedsætte et råd, der skal finde et fair og fornuftigt mål for reduktionen af CO2 i landbruget, indgåelse af frivillige aftaler med landmændene om jordfordeling og udtagning af lavbundsjorde samt forskning i reduktion af metan fra husdyrbrug og lattergas fra planteproduktion.

Tempo for reduktionsmål:

Partiet overopfylder i forhold til EU's målsætninger og foreslår en vision, hvor vi er fri af fossile brændsler allerede i 2045 i stedet for i 2050. Ifølge udspillet har Danmark evne og pligt til at gå foran og tage den grønne førertrøje på og henviser her til, hvordan Socialdemokratiet historisk har været med til at gøre Danmark til frontløber på området.

$\varnothing$ konomi og finansiering:

Partiet vil genindføre det grønne nationalregnskab for at udvide vores viden om sammenhængen mellem miljø, naturressourcer og økonomi. Partiet vil endvidere afsætte midler til en ny grøn fremtidsfond på 20 mia. kr., der skal gå til investeringer i grøn teknologi. Den skal operere på markedsvilkår og forventes med tiden at generere afkast. Et internationalt Advisory Board skal bestå af den absolutte internationale investeringselite, virksomheder og forskere i grøn omstilling og vurdere de konkrete projekter.

Vækst og klima er ifølge partiet hinandens forudsætninger, og der er i udspillet fokus på at fremme de grønne private investeringer og en politisk regulering, der understøtter disse.

Der er igennem forslaget stort fokus på, hvordan den grønne teknologi har været en eksportvare og at det fortsat er en væsentlig drivkraft for den grønne udvikling, hvor de skriver: "Vi bliver rigere herhjemme, når vi formår at sælge danske produkter på udenlandske markeder.

I forhold til finansieringen af udspillet skriver de: "Tiltagene i Socialdemokratiets udspil er finansieret indenfor den ramme, som blev afsat med aftalen om PSO i efteråret 2016..." (Socialdemokratiet 2019, 34).

Udspillet rummer af den grund ikke specifikke opstillinger af udgifter og finansiering. Forslagene er ellers generelt konkrete, dog ikke hvad angår landbruget. 


\begin{abstract}
Alternativet
Landbrug:

Partiet peger på et $100 \%$ økologisk landbrug, en prissætning af fødevarerene afhængig af klimabelastningen, fossilfri landbrugsproduktion, udtagning af lavbundsjorde, stop for import af soja og kunstgødning $\mathrm{mm}$.

Derudover har partiet fokus på, at vi som forbrugere skal have en mere klimavenlig livsstil, hvor vi f.eks. skal spise mindre kød og flyve mindre, men det offentlige skal også gå foran med offentlige grønne indkøb.

Tempo for reduktionsmål:

Danmark bør gå foran, fordi vi har mulighed for det og har gjort det før.

Partiet peger på, at vi skal overopfylde målene i Parisaftalen, eftersom ikke engang opfyldelsen af Parisaftalen vil gøre det muligt at begrænse opvarmningen til 1,5 grad. Emissionerne skal falde markant langt inden 2030, hvis det mål skal nås.

Økonomi og finansiering:

Der skal indføres reparationsfradrag, pant på elektronik, længere reklamationsret, forbud mod planlagt forældelse m.v. Der skal ligeledes indføres klimaafgift på klimabelastende fødevarer. Finansiering af politikken er ikke del af udspillet.

Forslagene er konkrete og målsat, men der er ikke taget højde for finansiering af tiltagene.
\end{abstract}

\title{
Radikale
}

Landbrug:

Partiet foreslår udtagning af 1/3 af landbrugsarealet til anlæggelse af natur og skov, de vil bevæge landbrugsdriften i økologisk, giftfri retning, have mere forskning i landbrugsteknologi, der fører til klimavenligt landbrug, den enkelte bedrift skal føre klimaregnskab. Hertil kommer oprettelse af 10 nye vilde naturreservater uden marker og lignende, men for naturens skyld og fokus på drikkevandskvaliteten og derfor mindre sprøjtning i drikkevandsoplande $\mathrm{mm}$.

Tempo for reduktionsmål:

De vil med deres forslag gå foran, i forhold til hvad Danmark har forpligtet sig til og reducere CO2-udledningen med 60 \% i 2030 i forhold til 1990, hvor forpligtelsen lyder på $40 \%$.

Økonomi og finansiering: 
Enkelte steder i udspillet fokuseres der på den grønne eksport ved f.eks. at fremføre: "Vi har alle forudsætninger for at gøre dansk fødevareproduktion til det næste vindmølleeventyr." (Radikale 2019, 11). Der er ligeledes fremlagt beregninger af, hvordan forslaget skal finansieres.

Forslagene er konkrete og målsat, og det er ligeledes vist, hvordan forslaget skal finansieres.

\section{VKL-regeringen (Venstre, Konservative og Liberal Alliance) \\ Landbrug:}

VKL-regeringen skriver, at tiltagene i landbruget skal "... ske på en måde, så danske landmænd fortsat er konkurrencedygtige. Hvis danske landmænd taber konkurrencen med landmænd i lande, der forurener mere end os, gavner det ikke miljøet." (Regeringen 2018 , 5). I forslaget nævner de, at de vil igangsætte initiativer for at mindske ammoniak i luften, forbedre biogasanlæggene, fremme luft- og klimavenlig teknologi i svinestaldene m.v.

Tempo for reduktionsmål:

I udspillet lægger Regeringen op til at leve op til de forpligtelser, de har forpligtet sig til i EU og leve op til de mål, der er sat for 2020, 2030 og 2050 og lægger i forslaget op til løbende opfølgning på indsatsen i 2022, 2024 og 2027. Med grafisk fremstilling viser de, hvad Klimarådet efterfølgende påpegede, at nedgangen i CO2-udledningen mindskes betydeligt med dette forslag i forhold til tidligere. De kommenterer dog ikke på det som sådan.

Der er flere steder fokus på, at Danmark ikke kan gøre det alene eller gå foran, for vi er også afhængig af vores nabolande.

\section{Økonomi og finansiering:}

Regeringens forslag er det eneste, der peger på brugen af fleksibilitetsmekanismerne, som godt nok er inden for den kvotebelagte sektor, men også har betydning for, hvor konkrete forslagene er. De peger her på annullering af CO2-kvoter og de såkaldte LULUCF-kreditter. Begge dele indgår med tal for reduktioner i deres samlede regnskab, selvom mulighederne ved disse fleksibilitetsmekanismer er stærkt omdiskuterede.

Det er fremlagt, hvordan forslaget skal finansieres.

Forslagene er generelt konkrete, men på landbrugsområdet er de mindre konkrete. I forhold til fleksibilitetsmekanismerne fremstår forslagene som konkrete, men viser sig at være mindre konkrete. Der er gjort rede for finansieringen af forslagene. 


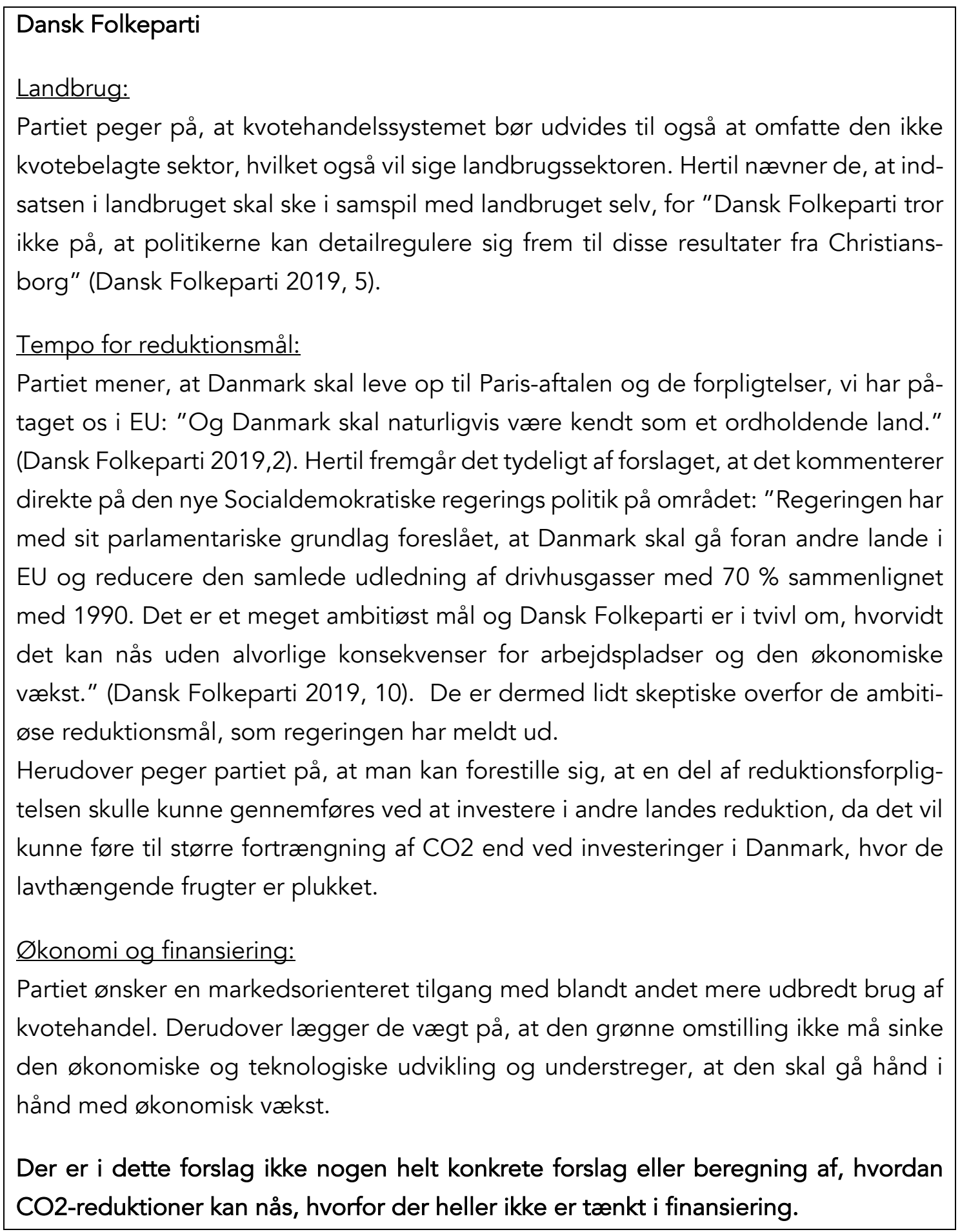

Hvert parti har på den måde sin egen forståelse af klima, men selvom forskellene er forsøgt fremhævet, er der også ligheder partierne imellem. Tilbage i 2009/10 viste der sig i analysen en relativ entydig forskel mellem de politiske fløje, hvor det mønster nu er knap så entydigt. Der viser sig stadig den største grad af forskel mellem fløjene, men der er også forskelle inden for de politiske fløje.

Det betyder, at der omvendt også viser sig ligheder på tværs af fløjene. F.eks. gælder det, at hverken VKL-regeringens, DF’s eller Socialdemokratiets forslag er særlig 
konkrete, hvad angår tiltag i landbruget. Regeringen nævner, at landbrugets konkurrencevilkår skal håndhæves, DF påpeger, at indsatsen med at reducere $\mathrm{CO} 2$ udslippet $\mathrm{i}$ landbruget skal ske i samspil med landbruget selv, mens Socialdemokratiet taler mere generelt om erhvervsinteresse. Ingen af dem gør det konkret, hvad det skal betyde for landbrugets nedbringelse af CO2-udslip. Heroverfor står alle de øvrige partier med en lang række konkrete forslag til reduktion af CO2-udslip i landbruget.

Alle udspil undtaget VKL-regeringens, DF's og Socialistisk Folkepartis første udspil har intentioner om at overopfylde forpligtelsen, mens VKL-regeringens, DF's og Socialistisk Folkepartis første udspil vil leve op til forpligtelsen. Socialistisk Folkeparti pointerer dog, at deres mål er reelt, mens VKL-regeringens mål ved f.eks. brug af fleksibilitetsmekanismerne ikke er reelle. På den måde er Socialistisk Folkeparti med til at påpege, hvordan fleksibilitetsmekanismerne kan gøre forslagene om CO2-reduktion mindre konkrete. I Socialistisk Folkepartis senere udspil "Hurtigt frem mod et klimaneutralt Danmark" melder de dog ind, at de vil overopfylde forpligtelsen og stræbe efter en CO2reduktion på 70 \% i 2030 (Socialistisk Folkeparti 2019b).

Alle udspil, undtagen Alternativets og DF's, gør rede for finansieringen af planerne. For Alternativet udgør det en særlig pointe. Alternativet ønsker, at deres politik tager udgangspunkt i klimaet frem for økonomien og peger derfor bevidst ikke på finansiering til deres klimatiltag. Hvad angår DF handler det i højere grad om, at deres udspil ved en langt senere lancering end de øvrige skal ses som en lidt anden slags udspil. Det forsøger at tage del i den klimapolitiske diskussion, der er fortsat efter valget og udspillet er, både hvad angår finansiering og forslag i det hele taget, langt mindre konkret end alle de øvrige udspil.

Enhedslisten, Alternativet, Socialdemokratiet og Radikale nævner specifikt ønsker om at gå foran og være et godt eksempel for andre lande, mens VKL-regeringens forslag peger direkte på, at vi ikke som sådan skal gå foran, for vi er afhængig af andre lande. DF påpeger, at Danmark allerede er et foregangsland på området.

På den måde er det ikke på alle områder en helt entydig kamp mellem de politiske fløje, og det kan være svært at se et klart kontinuum fra venstre til højre eller omvendt. Det er anderledes i forhold til analysen i 2009/10, hvor venstrefløjen var til et langsigtet fokus, men højrefløjen var til et mere kortsigtet fokus. Det indikerer dog også, hvad vi skal se på nu, at den generelle kommunikation om klima blandt politikerne har ændret sig på de 10 år.

\section{Kommunikationsformen i politisk klimakommunikation}

Efter at have vist forskellene på partiernes forståelse og kommunikation om klima skal vi nu undersøge, hvad der udgør den fælles ramme eller, udtrykt med Luhmann, kommunikationsformen for den politiske klimakommunikation. Det er den form, som al partipoli- 
tisk kommunikation om klima knytter an til, og som ikke er umiddelbar synlig, men afhængig af tid og kontekst og derfor foranderlig. Først fokuserer afsnittet på klimaudspillene fra 2018 og 2019 og dernæst på en sammenstilling med interviewene fra 2009/10. Det interessante er altså, hvad det er, der samler de forskellige partiers politiske forståelser af klima, og som samtidig viser sig som en umulighedsrelation: En umulighedsrelation, der driver kommunikationen dynamisk fremad i den politiske diskussion. Det er lige præcis relationen mellem at være 'konkret' og 'ukonkret', som ingen kan være på en og samme tid i den enkelte udmelding. Ethvert samlet udspil kan således godt indeholde både konkrete og ukonkrete elementer, men hvert enkelt element kan kun være enten konkret eller ukonkret. Det kan illustreres som i figur 1.

Det konkrete og ligeså det ukonkrete er i denne sammenhæng at forstå som specifikke beregninger og talværdier for alt fra økonomi, udslip af CO2 og f.eks. kvoters formåen på begge dele. Talværdier og beregninger er således den kommunikationsform, som den politiske kommunikation om klima knytter an til i udspillene - det er den logik, der dominerer den politiske diskussion om klima som konkret versus ukonkret. Her gælder det nemlig, at man både kan konkretisere og gøre mindre konkret ved hjælp af beregninger og talværdier. Det er i figur 1 illustreret ved, at beregninger og talværdier har indtaget pladsen for den blinde plet.

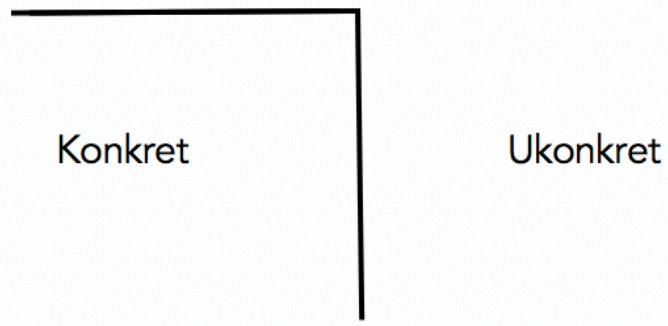

Talværdier og

beregninger

Figur 1: Grafisk illustration af at 'konkret' og 'ukonkret' er hinandens modsætning, men samtidig uadskillelige, og at talværdier og beregninger udfylder den blinde plet og udgør kommunikationsformen.

At tal og beregninger kan bruges både til konkretisering af klimapolitik og til at gøre klimapolitik mindre konkret, ser vi mest tydeligt i anvendelsen af fleksibilitetsmekanismerne, som VKL-regeringen gør brug af i deres udspil, hvor de vil annullere CO2-kvoter og anvende LULUCF-kreditter. Disse virkemidler er stærkt omdiskuterede i forhold til den reale nedgang i CO2-udslip. F.eks påpeger Klimarådet i deres seneste statusrapport, at den fremlagte nedgang i CO2-udslip på baggrund af disse virkemidler netop er beregninger, men ikke reelle mål for den konkrete nedgang i CO2 udslip (Klimarådet 2018). Det er baggrunden for, at Socialistisk Folkeparti kalder det "bogholderfiduser" i deres 
første udspil (Socialistisk Folkeparti 2019a, 4) og Alternativet betegner det "skrivebordsøvelser" og såkaldte "fleksibilitetsmekanismer" i deres udspil (Alternativet 2018, 12). På den måde kan beregninger altså også gøre noget ukonkret, og det er netop den skelnen, de politiske diskussioner kredser om.

Den politiske diskussion afspejler sig primært i to forhold, der tydeliggør forskellen mellem konkret og ukonkret. Det ene forhold er, hvorvidt partierne i deres politiske udspil har konkrete forslag både inden for den kvotebelagte sektor og den ikke kvotebelagte sektor, eller om de kun har det inden for den kvotebelagte sektor eller/og dele af den ikke kvotebelagte sektor. Sidstnævnte er gældende for Socialdemokratiets og VKL-regeringens udspil, mens de øvrige udspil dækker både den kvotebelagte og den ikke-kvotebelagte sektor med konkrete forslag. DF skiller sig igen ud ved at foreslå, at kvotehandelssystemet burde: “... udvides til på EU-plan også at omfatte landbrug, boliger og transport, som i dag er undtaget." (Dansk Folkeparti 2019, 4).

Det andet forhold er, om partierne lægger op til en strategi, hvor de kun lige lever op til EU's målsætninger og måske endda skubber en relativt stor del af opfyldelsen til sidst i hver af målperioderne, eller om de lægger op til at overopfylde i forhold til målsætningerne og dermed lægger opfyldelsen relativt tidligt i målperioden. Her ser vi i udspillene, at VKL-regeringen skubber en stor del af opfyldelsen af målene til sent i målperioden, at DF slet ikke har nogen indmeldinger på det, mens alle øvrige partiers udspil overopfylder og dermed placerer opfyldelse af målene tidligt i målperioden.

Sammenligner vi med analysen af interviewene fra 2009/10, har kommunikationsformen ændret sig. På det tidspunkt var der meget fokus på begreberne mitigation (nedbringelse af CO2-udslip) over for adaptation (tilpasning til klimaforandringerne), hvilket politikerne også talte om, men mest udfyldte med ord omkring det at have et langsigtet eller et kortsigtet perspektiv (Almlund 2012). Politikere og partier med et langsigtet perspektiv var fokuserede på nedbringelse af $\mathrm{CO} 2$-udslippet, mens partier med et mere kortsigtet perspektiv var mere optagede af tilpasning til klimaforandringerne. Ved den analyse var det dermed mitigation versus adaptation, der var den umulighedsrelation, der bragte den politiske kommunikation om klima fremad.

Den politiske diskussion hvilede derudover på at tale om ressourcer, og ressourcer indtog pladsen for den blinde plet, for der var i alle interview et stærkt fokus på ressourcer (se. Figur 2). Der var imidlertid tanke på både menneskelige ressourcer og økonomiske ressourcer, hvor tendensen var, at de partier, der var mest optagede af mitigation og det langsigtede perspektiv, talte mest om menneskelige ressourcer, mens de partier, der var mere optagede af adaptation og det kortere perspektiv mest talte om økonomiske ressourcer. 


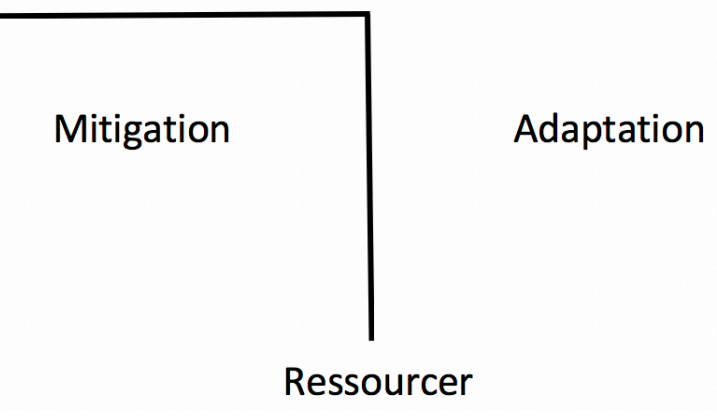

Figur 2: Grafisk illustration af at 'mitigation' og 'adaptation' var hinandens modsætning, men samtidig uadskillelige, og at ressourcer udfylder den blinde plet og udgør kommunikationsformen.

Ændringen fra 2009/10 og til 2018/19 er, at den politiske diskussion og forståelse af klima er gået fra at bevæge sig på et overordnet niveau med fokus på mere abstrakte begreber og tanker til at bevæge sig på et mere konkret niveau. Den er gået fra et fokus på, hvorvidt det gav mening at nedbringe CO2-udslippet eller at tilpasse sig de forandringer, der nu måtte være, til et fokus på, hvilke konkrete tiltag, der skal iværksættes for at opfylde målene fastsat af EU eller i de lidt mere vidtgående partier af partierne selv.

Den forandring er dog ikke udtryk for, at partierne trækker på videnskabelig viden, der først er tilvejebragt nu. Faktisk er der nok tale om, at det meste af den viden, som politikerne nu læner sig op af for at konkretisere deres intentioner, også forelå tilbage i 2009/10, men som altså ikke i tilstrækkelig grad har forstyrret det politiske system i dets kommunikation om klima.

\section{Konkluderende bemærkninger}

Analyserne viser os, hvordan det politiske system mere generelt har udviklet sig fra et fokus på ressourcer og diskussionen mellem mitigation og adaptation for ti år siden til i dag at have fokus på talværdier og beregninger og diskussioner mellem at være konkret og ukonkret. Helt overordnet tegner der sig et billede af, at politikerne i langt højere grad end tidligere trækker på den videnskabelige viden og klimamodellernes beregninger i deres langt mere konkrete udspil på området, end de gjorde for ti år siden og for nogle partiers vedkommende for bare et par år siden.

Generelt skiller DF sig dog ud ved ikke at være særlig konkrete i deres forslag, men måske mest af alt ved først at melde sig på banen på det her politiske område langt senere end de øvrige partier og efter at have negligeret det i mange år. På den måde kan en af de store forandringer, der er sket i den politiske kommunikation om klima også siges at være, at DF nu melder sig ind i diskussionen om klima, ligesom de også var tilbage $\mathrm{i}$ 2009, men faktisk ikke har været i den mellemliggende periode.

Som andre har påpeget for mig, er der ikke nogen lige linje fra videnskab til politik (Lahn \& Sundqvist 2017), så selvom den videnskabelige viden kan siges at have fordret 
politisk bevågenhed, så er det ikke alene i den videnskabelige viden, vi skal finde svaret på, at politikerne er stærkere og mere konkret fokuserede på klimapolitik nu, end de var det for 10 år siden. Den primære grund skal formodentlig, som antydet i indledningen, findes i borgernes og dermed vælgernes foruroligelse.

Derudover er den videnskabelige viden om klima dog også blevet konkretiseret med forfinelse af modeller, forventninger, beregninger mm., der blandt andet sker gennem IPCC's arbejde og EU's arbejde og på mere nationalt plan blandt andet gennem Klimarådets arbejde. Det har gjort beregninger på klimaområdet mere tilgængelige og sværere at ignorere også i det nationale politiske virke. Så selvom der på de store linjer ikke er sket afgørende kvalitative ændringer med den videnskabelige viden om problemets alvor, så er der i de mere og mere detaljerede beregninger skabt grobund for et stærkere fokus på netop beregninger og konkretisering.

På den måde er klimapolitik blevet tallenes og beregningernes politik, eftersom det er tal og beregninger, der er blevet den kommunikationsform, der skaber rammen for den politiske kommunikation om klima. Det gør ikke nødvendigvis de politiske tiltag fuldt ud gennemskuelige, eftersom tal og beregninger både kan bruges til at gøre de politiske tiltag meget konkrete, men også få dem til at se konkrete ud, når de ikke er det.

Derfor er det et åbent spørgsmål, om beregninger i tilstrækkelig grad fanger de politiske forskelle, eller om vi netop skal have blik for, at tal og beregninger er den kommunikationsform, som den politiske og ideologiske kommunikation knytter sig til for nuværende og ikke siger noget entydigt om, hvor konkrete tiltagene er.

\section{Litteratur}

Almlund, P. (2020). Politik er kommunikation - systemteoretisk set. I: N. M. Nielsen \& K. Pedersen, red., Politisk kommunikation i humanistisk perspektiv. Djøfs Forlag. Almlund, P. (2012). Negotiating and Communicating Climate. I: P. Almlund, P. H. Jespersen og S. Riis, red., Rethinking Climate Change Research. Clean Technology, Culture and Communication. London: Ashgate. https://doi.org/10.4324/9781315605999

Almlund, P. (2007). Miljøkommunikation i virksomheder - praksis $i$ kontekstens blinde plet. Ph.d.-afhandling. Institut for Kommunikation, Virksomhed og Informationsteknologier. Roskilde: Roskilde Universitetscenter.

Almlund, P. og Danielsen, O. (2016). Det hjemløse klima. I: M. Blach-Ørsten \& I. Willig, red., Den falles dagsorden og alle de andre. En nyhedsugeanalyse af medieindhold, mediebrug og medieforventninger. København: Samfundslitteratur.

Andersen, N. Å. (2014). Den semantiske analysestrategi og samtidsdiagnostik. I G. Harste \& M. Knudsen, red., Systemteoretiske analyser. At anvende Luhmann. København: Nyt fra Samfundsvidenskaberne.

Andersen, N. Å. (2003). Borgernes kontraktliggørelse. København: Hans Reitzels Forlag. 
Andersen, N. Å. (1999). Diskursive analysestrategier. Foucault, Koselleck, Laclau, Luhmann. København: København: Nyt fra Samfundsvidenskaberne.

Danielsen, O. (2015). Klimaet på dagsordenen. København: Multivers.

Denzin N. K. \& Lincoln, Y.S. (2003). Introduction: The Discipline and Practice of Qualitative Research. I: N. K. Denzin \& Y. S. Lincoln, red., Strategies of Qualitative Inquiry. Second edition. Thousand Oaks: Sage Publications.

Eskjær, M. F. (2016). Climate change communication in Denmark. I: Oxford Research Encyclopedia of Climate Science. Oxford University Press.

Eskjær, M. F. (2014). Den danske presses klimadækning før og efter COP 15. I: M. Sørensen \& M. F. Eskjær, red., Klima Og Mennesker. Humanistiske perspektiver på klimaforandringer. København: Museum Tusculanum.

Klimarådet (2018). Status for Danmarks klimamålsatninger og -forpligtelser 2018.

Klingenberg, K. (2009). Nyt i 2009: Sexting og klimakvalme. Fyens.dk. Tilgængelig på: https://fyens.dk/artikel/nyt-i-2009-sexting-og-klimakvalme[Tilgået d. 28.10.19].

Kneer, G. \& Nassehi, A. (1997). Niklas Luhmann - introduktion til teorien om sociale systemer. København: Hans Reitzels Forlag.

Kvale, S. \& Brinkmann, S. (2015). Interview. Det kvalitative forskningsinterview som håndvcerk. 3. udgave. København: Hans Reitzels Forlag.

la Cour, A., Knudsen, M. \& Thygesen, N. T. (2005). Det systemteoretiske interview Interviewet som meningsdannelse. MPP Working Paper, nr. 8. Department of Management, Politics and Philosophy.

Lahn, B \& Sundqvist, G. (2017). Science as a "fixed point"? Quantification and boundary objects in international climate politics. Environmental Science \& Policy, nr. 67, s. 8-15.

Luhmann, N. (2016). Samfundets samfund. København: Hans Reitzels Forlag.

Luhmann, N. (2002). Massemediernes realitet. København: Hans Reitzels Forlag.

Luhmann, N. (2000). Sociale systemer. Grundrids til en almen teori. København: Hans Reitzels Forlag.

Luhmann, N. (1997). Iagttagelse og paradoks. København: Gyldendal.

Luhmann, N. (1995). The paradoxy of observing System. Cultural Critique, nr. 31, s. $37-$ 55.

Luhmann, N. (1992). Operational closure and structural coupling: The differentiation of the legal system. Cardozo law review, årg. 13, s. 1419-1441.

Luhmann, N. (1990). Political Theory in the Welfare State. Berlin, New York: Walter de Gruyter.

Nielsen, J. S. (2009). Klimakvalme. Information. Tilgængelig på: https://www.information.dk/debat/leder/2009/04/klimakvalme [Tilgået d. 28.10.19]

Søgaard, F. (2019). Nye tal: Ingen partier når i mål med CO2-neutralitet i 2050. Altinget.dk. Tilgængelig på: https://www.altinget.dk/artikel/nye-tal-ingen-partiernaar-i-maal-med-co2-neutralitet-i-2050 [Tilgået d. 28.10.19] 
De politiske udspil

Alternativet (2018). Alternativets klimaplan 2010. Oktober 2018.

Alternativet (2018a). Mindre fossil mere vedvarende energi.

Dansk Folkeparti (2019). Et grønt Danmark med borgeren i centrum. Klimapolitik. September 2019.

Enhedslisten (2019). Enhedslistens klimaplan 2030: En socialt retfoerdig vej til det grønne samfund. 13. februar, 2019.

Liberal Alliance (2019). Et Danmark med overskud. Liberal Alliances 2030-plan.

Radikale (2018). Klima 2030 - et grønt Danmark der leder verden. Et radikalt klimaudspil, marts 2018.

Radikale (2019). Klimaet kalder FREMAD. Marts 2019.

Socialdemokratiet (2019). Danmark skal igen vare en grøn stormagt. En klima- og miljøpolitik der samler Danmark.

Socialdemokratiet (2019a). Danmark skal igen vare en grøn stormagt. Vi efterlader ikke miljø- og klimakrisen til noeste generation.

Socialistisk Folkeparti (2018). Transportsektorens CO2-udslip skal ned - og vi starter nu. 8. oktober, 2018.

Socialistisk Folkeparti (2019a). En cegte klimaindsats i landbruget. 2. januar, 2019.

Socialistisk Folkeparti (2019b). Hurtigt frem mod et klimaneutralt Danmark. 25. maj, 2019. 